Morphogenetic, Ontogenetic and Diurnal Variability in Content And Constituents of Bitter Fennel (Foeniculum vulgare Miller var. vulgare) Essential Oil*

Muhammed Akif AÇIKGÖZ ${ }^{1}$, Şevket Metin KARA ${ }^{2}$

Department of Field Crops, Faculty of Agriculture, Ordu University, 52200 Ordu, Turkey ${ }^{1}$ https://orcid.org/0000-0003-2436-5605, ${ }^{2}$ https://orcid.org/0000-0001-7755-1394

$\bowtie$ : makifacikgoz@gmail.com

\section{Research Article}

$\begin{array}{ll}\text { Article History } & \\ \text { Received } & : 25.07 .2019 \\ \text { Accepted } & : 07.10 .2019\end{array}$

\section{Keywords}

Alpha-pinene

Fenchone

Trans-anethole

Volatile oil

\title{
Acı Rezene (Foeniculumvulgare Miller var. vulgare) Uçucu Yağ İçeriği ve Bileşenlerinde Morfogenetik, Ontogenetik ve Diurnal Varyabilite
}

\section{ÖZET}

$\mathrm{Bu}$ çalışma acı rezene uçucu yağ içeriği ve bileşenlerinde morfogenetik, ontogenetik ve diurnal varyabilitenin belirlenmesi amacıyla yürütülmüştür. Çiçeklenme öncesi, tam çiçeklenme ve çiçeklenme sonrasında ve günün farklı saatlerinde (09:00, 13:00 ve 17:00) hasat edilen bitki organlarının (yaprak, kök-yumru-sap, çiçek ve tohum) uçucu yağları hidrodistilasyon yoluyla çıkarılarak, gaz kromatografisi ve kütle spektrometresi ile analiz edilmiştir. Yaprak < çiçek < tohum sıralamasıyla artış gösteren uçucu yağ içeriği, bitki organı ve büyüme dönemine bağlı olarak önemli değişiklik göstermiş ve tohumda uçucu yağ içeriği yaprağa göre yaklaşık 7 kat daha fazla olmuştur. Uçucu yağ içeriği çiçeklenme öncesinde \%1.68'den tam çiçeklenmede \%2.18'e yükselmiş, fakat çiçeklenme sonrasında \%0.81'e düşmüştür. Tohum $>$ çiçek $>$ kök-yumru-sap $>$ yaprak sıralamasıyla azalan trans-anetol bütün uçucu yağlarda en önemli komponent olarak belirlenmiştir. Büyüme dönemi ve bitki organına göre değişim gösteren alfa-pinen, alfa-fellandrene, limonene ve fenkon diğer önemli komponenetlerdir. Sunulan bu çalışma, Türkiye orijinli acı rezenenin uçucu yağ içeriği ve bileşenlerinin esas olarak bitki organı ve büyüme dönemine göre belirlendiğini ortaya koymuştur.

\section{Araştırma Makalesi}

Makale Tarihçesi
Geliş Tarihi $\quad: 25.07 .2019$

Kabul Tarihi : 07.10.2019

\section{Anahtar Kelimeler}

Alfa-pinen

Fenkon

Trans-anetol

Uçucu yağ

To Cite : Açıkgöz MA, Kara ŞM 2020. Morphogenetic, Ontogenetic and Diurnal Variability in Content And Constituents of Bitter Fennel (Foeniculum vulgare Miller var. vulgare) Essential Oil. KSU J. Agric Nat 23 (1): 127-134. DOI: 10.18016/ksutarimdoga.vi.596542

INTRODUCTION

Fennel (Foeniculum vulgare Miller) is an ancient medicinal and aromatic plant belonging to the Apiaceae family. Used by humans since ancient times, 
it is now widely cultivated throughout the temperate and tropical regions of the world (He and Huang, 2011; Badgujar et al., 2014). Fennel fruit and its volatile oil are used as a culinary spice, food flavoring agent, and constituents in cosmetic, perfumery and pharmaceutical products (Rather et al., 2016). Medicinal, aromatic and pharmacological properties of fennel are associated with the presence of essential oil containing a complex mixure of chemical compounds with certain bioactive properties (Khan and Musharaf, 2014). Essential oil of fennel has antioxidant (Kara and Acikgoz, 2018), anti-inflammatory (Choi and Hwang, 2004), antibacterial (Acikgoz et al., 2017) and antifungal (Ozcan et al., 2006) activities. The major constituents of fennel essential oil are transanethole (anothole-E), estragole (methyl chavicol), $\alpha^{-}$ phellandrene, fenchone, $\alpha$-pinene, and limonene (Rather et al., 2016). Several internal and external factors affect the content, chemical composition and bioactive properties of fennel essential oil, including part of the plant (Stefanini et al., 2006), stage of maturity (Telci et al., 2009), geographical origin (Bahmani et al., 2016), environmental and climate conditions (Figueredo et al., 2011), and also agronomic practices (Coban et al., 2018). It has been suggested that a study on a plant as a source of flavoring, such as fennel, requires analysis of not only its seeds but also other parts of the plant harvested at different growth stages (Stefanini et al., 2006). There are, hovewer, limited findings on the content and constituents of essential oil of Turkish fennel as affected by plant organ, growing stage and harvesting time. It has been reported that the content of Turkish bitter fennel essential oil was higher in early growth stages than in the latter ones (Ozcan et al., 2006; Telci et al., 2009). Some studies suggested that the major component of Turkish fennel essential oil was trans-anethole (Cosge et al., 2008; Coban et al., 2018), whereas a few works showed the predominance of estragole as the main constituent (Ozcan and Akgul, 2001; Ozcan et al., 2006). These conradictory results imply that further studies are needed concerning plant type (bitter or sweet), plant organ and growth stage based variability in content and consitituents of bitter fennel essential oil. Further, to the best of our knowledge, there is no study on diurnal variabilty in content and chemical composition of fennel essential oil. Thus, this study was carried out to determine morphogenetic, ontogenetic and diurnal variability in content and constituents of essential oil of bitter fennel (Foeniculum vulgare Miller var. vulgare) grown in Turkey.

\section{MATERIAL and METHODS}

\section{Plant material}

Land race of bitter fennel (Foeniculum vulgare Mill. var. vulgare) was used in the present study and the seeds were obtained from the Department of Field Crops, Faculty of Agriculture of Ankara University of Turkey. Field study was carried out in the Research Station of Agricultural Faculty of Ordu University in Ordu province (latitude $40.98^{\circ} \mathrm{N}$, longitude $37.87^{\circ} \mathrm{E}$, altitude $5 \mathrm{~m}$ ) located in the coastline of the central Black Sea Region of Turkey in 2012 and 2013 years. A total of 500 fennel plants were grown on a slightly acidic clay loam soil with adequate level of nitrogen and average levels of potassium, phosphorous and organic matter. The seeds were sown in rows of 4 meters at a $40^{-} \mathrm{cm}$ row distance and basic fertilization was applied before planting at the rates of $50 \mathrm{~kg} \mathrm{ha}^{-1} \mathrm{~N}$ and $50 \mathrm{~kg} \mathrm{ha}^{-1} \mathrm{P}_{2} \mathrm{O}_{5}$.

\section{Sample preparation}

Plant samples were harvested from different organs at different times to determine three types of variabilities, namely ontogenetic, morphogenetic and diurnal. To determine morphogenetic variability leaf, root-bulb-stalk, flower and seed samples were analyzed. The leaf and root-bulb-stalk samples were taken at pre-, full-, and post-flowering stages. The flower samples were picket at full flowering, and the seed samples were gathered at the beginning of seed formation and seed maturity. To determine onthogenetic and diurnal variability, the whole plant samples of pre-, full- and post-flowering stages were harvested at three times in a day; at $9 \mathrm{am}, 1$ and $5 \mathrm{pm}$.

\section{Isolation of essential oil}

The plant samples were dried at $60{ }^{\circ} \mathrm{C}$ in an oven until constant weight is attained and grounded for isolation of essential oil. Essential oils of the plant samples were extracted using hydro-distillation method with the standard Clevenger apparatus. A $50 \mathrm{~g}$ of finely grounded sample was watered with $300 \mathrm{ml}$ distilled water. The distillation process lasted for approximately 4 hours at boiling point. The oil phase was separated and then dried over anhydrous sodium sulfate to remove water, filtered, and stored in a dark glass bottle at $4{ }^{\circ} \mathrm{C}$ until analyzed. All tests were made in triplicate.

\section{Analysis of essential oil constituents}

Determination of essential oil constituents was conducted by GC-MS analysis, using Shimadzu GC-QP 2010 Plus equipped with a DB-5MS capillary column $(30 \mathrm{~m} \times 0.25 \mathrm{~mm} \times 0.25 \mu \mathrm{m})$ and $\mathrm{MS}$ detector. Helium was used as the carrier gas at the constant flow of 1.0 $\mathrm{ml} \mathrm{min}^{-1}$ and mass spectra was taken at $70 \mathrm{eV}$. The oven temperature was held at $60{ }^{\circ} \mathrm{C}$ for $2 \mathrm{~min}$, and then programmed to $280^{\circ} \mathrm{C}$ at a rate of $10^{\circ} \mathrm{C} \mathrm{min}-1$, and held for $15 \mathrm{~min}$. Essential oil compositions were identified by calculation of their retention indices for $n$-alkanes (C5-C22) and the oil on a HP 5MS column. The constituents of essential oils were reported as a 
relative percentage of the total oil content of each sample. Essential oil and its constituents were given with their retention indices as relative to n-alkans (C5C22) on HP 5MS column (Adams, 2017).

\section{Statistical analysis}

The obtained data for essential oil content and constituents (main components) were subjected to variance analysis using a completely randomized design. The significance test for comparing the differences among the means was carried out with LSD ( $p<0.05)$ using Minitab 17 statistical software.

\section{RESULTS and DISCUSSION}

\section{Essential oil contents}

The values presented here were given as the average of the two study years, since non-significant differences were observed among essential oil contents of fennel plants grown in 2012 and 2013 years. Essential oil contents varied significantly $(p<0.05)$ with plant organ and ontogenetical phase of bitter fennel (Table 1 and Table 2). Daily harvesting time, however, did not produce any significant effects on essential oil contents (Table 2). A large variation in essential oil content due to plant organ and growth stage was detected, ranging from the lowest $(0.22 \%)$ in the root-bulb-stalk samples of post-flowering to the highest (4.51\%) in immature seeds. The mean essential oil content in root-bulb-stalk, leaf, flower and seed were $0.25 \%, 0.64 \%, 1.34 \%$ and $4.45 \%$, respectively. These findings show that, essential oil contents of bitter fennel increase regularly with the progress in plant growth; the later the plant growth stage, the higher is the essential oil content. When considering each plant organ separately, however, this turned vice versa and the essential oil content decreased with the maturity. Essential oil contents in leaf, for instance, decreased from $0.80 \%$ at pre-flowering to $0.65 \%$ at fullflowering and to $0.47 \%$ at post-flowering. Similarly, immature seeds produced higher amount of essential oil than mature seeds. Essential oil content of the whole plant samples increased from $1.68 \%$ at preflowering to $2.18 \%$ at full-flowering and decreased sharply to $0.81 \%$ at post-flowering. The accumulation of plant essential oils and their constituents among plant organs from roots to seeds is highly changeable. Various studies indicate that essential oil content vary greatly due to plant organs and growing stages in particular (Anwar et al., 2009; Ferioli et al., 2017; Wahba et al., 2018). Quantitative composition of fennel essential oil has been reported to be mostly dependent on ontogenetical phase and plant organ and most of essential oil accumulates in reproductive organs (Marotti et al., 1994; Lee and Ding, 2016). Our results corroborate these previous findings, revealing that the highest amount of essential oil accumulated in seed. Most of the previous studies were focused on volatile oil contents of leaf, fruit and seed, whereas a few reports were on those of root, bulb, stem, and flower (Figueredo et al., 2011; Bahmani et al., 2016; Khammassi et al., 2018). It has been reported that fennel seed produced much higher essential oil than stem and leaf (García-Jiménez et al., 2000; Stefanini et al., 2006). Ferioli et al., (2017) announced that a significant increase in essential oil content occurred from leaves to florets $(+105 \%)$ and from florets to fruits $(+135 \%)$. Essential oil content of bitter fennel in our study was comparable to those reported by Cosge et al. (2008) and Coban et al. (2018) in bitter fennel native to Turkey, while lower than that given by Ozcan et al. (2006), varying from $6.01 \%$ (unripe fruit) to $4.41 \%$ (ripe fruit) in Turkish bitter fennel. Plants generally synthesize essential oils in young cells and volatile compounds are largely accumulated even before the organ is fully expanded (Lee and Ding, 2016). In general, essential oil content decreases with the progress in seed development, which is confirmed in this study.In a study with bitter fennel originated from Turkey, Telci et al. (2009) stated that volatile oil content in early fruit growth stages was higher than that in later stages and usually decreased according to the progress in fruit growth. Similarly, Ozcan et al. (2006) found that essential oils of bitter fennel fruits decreased during subsequent developing periods. These findings are in good agreement with the results of the present study, indicating that immature mature seeds accumulated higher essential oil than mature seeds. These results, however, differed from those of Anwar et al. (2009), who reported that the lowest essential oil occurred in immature fruit $(2.8 \%)$, but essential oil increased significantly at intermediate $(3.2 \%)$ and mature growth stage (3.5\%). Despite of existing papers on essential oil content of fennel affected by plant organ and growing stage, there are no previous studies on diurnal variability (the effect of daily harvesting time) in bitter fennel essential oil. Thus, comparing our results with those of previous studies is not possible, except for the findings of Acikgoz et al. (2017) and Kara and Acikgoz (2018), in line with our results, who reported non-significant diurnal variability in antimicrobial and antioxidant activity of bitter fennel.

\section{Essential oil constituents}

Essential oil constituents were affected significantly $(p<0.05)$ by plant organ and ontogenetical phase of bitter fennel, with a non-significant effect of different daily harvesting time (Table 1 and Table 2). Gas chromatography and mass spectrometry analysis revealed the presence of 27 compounds in all essential oils representing $87.43-98.61 \%$ of total oil composition with the remaining in trace amounts $(<1.00 \%)$. Oxygenated monoterpenes (basically trans-anethole and fenchone) and monoterpene hydrocarbons (mainly 
Table 1. The content (\%) and constituents of volatile oil in different organs and phenological stages of Foeniculum vulgare Miller var. vulgare.

Tablo 1. Foeniculum vulgare Miller var. vulgare.'nin farklı organ ve gelişsme dönemlerindeki uçucu yağ bileşenleri ve miktarı (\%).

\begin{tabular}{|c|c|c|c|c|c|c|c|c|c|c|c|c|c|c|}
\hline \multirow[b]{2}{*}{ No } & \multirow[b]{2}{*}{ Compounds } & \multirow[b]{2}{*}{$\begin{array}{l}\mathrm{RI} \\
\text { Adams }\end{array}$} & \multicolumn{3}{|c|}{ Leaf } & \multicolumn{4}{|c|}{ Root-bulb-stalk } & \multicolumn{2}{|r|}{ Flower } & \multicolumn{2}{|c|}{ Seed } & \multirow[b]{2}{*}{ Mean } \\
\hline & & & $\begin{array}{l}\text { Pre- } \\
\text { flowering }\end{array}$ & $\begin{array}{l}\text { Full } \\
\text { flowering }\end{array}$ & $\begin{array}{l}\text { Post } \\
\text { flowering }\end{array}$ & Mean & $\begin{array}{l}\text { Pre- } \\
\text { flowering }\end{array}$ & $\begin{array}{l}\text { Full } \\
\text { flowering }\end{array}$ & $\begin{array}{l}\text { Post } \\
\text { flowering }\end{array}$ & Mean & $\begin{array}{l}\text { Full } \\
\text { flowering }\end{array}$ & Immature & Mature & \\
\hline 1 & Thujene $<a->$ & 930 & $\operatorname{tr}$ & 0.10 & 0.15 & $\operatorname{tr}$ & nd & nd & nd & nd & 0.18 & nd & nd & nd \\
\hline 3 & Camphene & 954 & 0.11 & 0.19 & 0.13 & 0.14 & nd & nd & nd & nd & nd & nd & nd & nd \\
\hline 4 & Sabinene & 975 & 0.10 & 0.10 & nd & $\operatorname{tr}$ & 0.20 & 0.14 & nd & 0.11 & nd & nd & nd & nd \\
\hline 5 & Pinene $<\beta->$ & 979 & 0.19 & 0.25 & 0.22 & 0.22 & nd & nd & nd & nd & 0.22 & 0.27 & 0.20 & 0.24 \\
\hline 6 & Myrcene & 990 & 0.28 & 0.46 & 0.13 & 0.29 & 0.43 & 0.28 & 0.25 & 0.32 & 0.23 & 0.31 & 2.30 & 1.31 \\
\hline 8 & Terpinene $<\alpha^{-}>$ & 1017 & nd & nd & nd & nd & nd & nd & nd & nd & 0.12 & 0.18 & 1.1 & 0.64 \\
\hline 9 & Cymene $<\rho^{->}>$ & 1024 & 4.22 & 2.28 & 1.46 & 2.65 & 3.10 & 1.22 & nd & 1.44 & 2.19 & 2.35 & 3.75 & 3.05 \\
\hline 10 & Limonene & 1029 & $6.25 \mathrm{~d}$ & $8.32 \mathrm{~b}$ & $6.94 \mathrm{c}$ & 7.17 & $3.58 \mathrm{e}$ & $2.32 \mathrm{~g}$ & $1.61 \mathrm{~h}$ & 2.50 & $10.20 \mathrm{a}$ & $3.48 \mathrm{e}$ & $2.70 \mathrm{f}$ & 3.09 \\
\hline 11 & 1,8-Cineole & 1031 & 0.17 & 0.21 & 0.14 & 0.17 & nd & nd & nd & nd & 0.10 & nd & nd & nd \\
\hline 12 & Ocimene $<(Z)-6->$ & 1037 & 0.17 & 0.22 & 0.29 & 0.23 & 0.12 & 0.12 & 0.12 & 0.12 & $\operatorname{tr}$ & $\operatorname{tr}$ & 1.32 & 0.66 \\
\hline 13 & Ocimene $<(\mathrm{E})-\mathrm{b}->$ & 1050 & nd & nd & nd & nd & nd & nd & nd & nd & nd & nd & 0.24 & 0.12 \\
\hline 14 & Terpinene $<\mathrm{Y}^{->}$ & 1059 & 1.02 & 1.54 & 0.75 & 1.10 & 6.02 & 4.54 & 4.63 & 5.06 & 0.54 & 0.66 & 0.70 & 0.68 \\
\hline 15 & Fenchone & 1086 & $4.34 \mathrm{e}$ & $4.50 \mathrm{e}$ & $6.22 \mathrm{~d}$ & 5.02 & $7.54 \mathrm{c}$ & $6.12 \mathrm{~d}$ & $6.05 \mathrm{~d}$ & 6.57 & $7.54 \mathrm{c}$ & $14.80 \mathrm{~b}$ & $15.70 \mathrm{a}$ & 15.25 \\
\hline 16 & Terpinolene & 1088 & nd & nd & nd & nd & nd & nd & nd & nd & 0.10 & nd & nd & nd \\
\hline 19 & Borneol & 1169 & nd & 0.10 & 0.10 & $\operatorname{tr}$ & nd & nd & nd & nd & nd & nd & nd & nd \\
\hline 20 & Terpinen-4-ol & 1177 & 0.32 & 0.35 & 0.41 & 0.36 & 1.35 & 0.35 & 0.35 & 0.68 & 0.44 & 0.48 & 1.51 & 1.00 \\
\hline 21 & Terpineol $<\alpha^{-}>$ & 1188 & 0.41 & 0.40 & 0.34 & 0.38 & 0.47 & 0.32 & 0.32 & 0.37 & 0.42 & 0.53 & 0.50 & 0.52 \\
\hline 22 & Estragole & 1196 & 3.75 & 3.20 & 3.41 & 3.45 & 5.07 & 2.20 & 2.01 & 3.09 & 2.24 & 3.10 & 3.82 & 3.46 \\
\hline 23 & Fenchyl acetate (exo) & 1232 & 0.23 & 0.25 & 0.25 & 0.24 & 0.21 & 0.20 & 0.18 & 0.20 & 0.10 & 0.17 & 0.14 & 0.15 \\
\hline 24 & Anethole (Z) & 1252 & 0.60 & nd & nd & 0.20 & nd & 0.35 & 0.42 & 0.26 & 0.75 & 0.80 & 0.88 & 0.84 \\
\hline 25 & Anethole (E) & 1284 & $37.60 \mathrm{e}$ & $29.64 \mathrm{f}$ & $38.53 \mathrm{e}$ & 35.26 & $41.80 \mathrm{~d}$ & $48.54 \mathrm{~b}$ & $46.20 \mathrm{c}$ & 45.51 & $54.75 a$ & $56.2 \mathrm{a}$ & $45.9 \mathrm{c}$ & 51.1 \\
\hline 26 & Anisaldehyde (meta) & 1196 & 0.10 & 0.10 & nd & $\operatorname{tr}$ & 0.10 & 0.12 & 0.10 & 0.11 & tr & $\operatorname{tr}$ & $\operatorname{tr}$ & $\operatorname{tr}$ \\
\hline 27 & Germacrene D & 1481 & 0.20 & $\operatorname{tr}$ & 0.10 & 0.10 & 0.10 & 0.10 & $\operatorname{tr}$ & $\operatorname{tr}$ & 0.20 & 0.15 & 0.18 & 0.16 \\
\hline \multirow[t]{8}{*}{28} & Caryophyllene oxide & 1583 & nd & nd & nd & nd & nd & nd & nd & nd & 0.30 & 0.40 & 0.25 & 0.33 \\
\hline & Monoterpen hydrocarbons & & 48.58 & 59.16 & 47.92 & 51.89 & 33.72 & 33.87 & 30.85 & 32.81 & 29.72 & 13.45 & 22.67 & 18.06 \\
\hline & Monoterpen oxygeneted & & 48.02 & 39.10 & 50.09 & 45.74 & 55.08 & 58.83 & 56.3 & 56.64 & 67.16 & 77.04 & 70.08 & 73.56 \\
\hline & Sesquiterpen hydrocarbons & & 0.20 & $\operatorname{tr}$ & 0.10 & 0.10 & 0.10 & 0.10 & $\operatorname{tr}$ & $\operatorname{tr}$ & 0.20 & 0.15 & 0.18 & 0.11 \\
\hline & Sesquiterpen oxygeneted & & nd & nd & nd & nd & 0.10 & 0.10 & 0.10 & 0.10 & 0.30 & 0.40 & 0.25 & 0.33 \\
\hline & Others & & 0.33 & 0.35 & 0.25 & 0.31 & 0.31 & 0.32 & 0.28 & 0.30 & 0.10 & 0.17 & 0.14 & 0.11 \\
\hline & Volatile oil yield (\%) & & $0.80 \mathrm{c}$ & $0.65 \mathrm{~d}$ & $0.47 \mathrm{e}$ & 0.64 & $0.30 \mathrm{f}$ & $0.24 f$ & $0.22 f$ & 0.25 & $1.34 \mathrm{~b}$ & $4.51 \mathrm{a}$ & $4.39 a$ & 4.45 \\
\hline & All identified components & & 97.13 & 98.61 & 98.26 & & 89.21 & 93.12 & 87.43 & & 97.48 & 91.21 & 93.32 & \\
\hline
\end{tabular}

RI Adams: Identification based on comparison of retention index those of published data (Adams, 2017), Retention indices relative to n-alkans (C5-C22) on HP 5MS column, tr: Trace (<0.1). 
Table 2. The content (\%) and constituents of volatile oil of the whole plant samples of Foeniculum vulgare Miller var. vulgare in different phenological stages and at different harvesting times.

Tablo 2. Foeniculum vulgare Miller var. vulgare.'nin tüm bitki örneklerinin farklı gelişme dönemlerinde ve farklı hasat zamanlarında uçucu yağ bileşenleri ve miktarı (\%).

\begin{tabular}{|c|c|c|c|c|c|c|c|c|c|c|c|c|c|c|}
\hline \multirow{4}{*}{$\begin{array}{l}\text { No } \\
1\end{array}$} & \multirow[b]{3}{*}{ Compounds } & \multicolumn{5}{|c|}{ Pre-flowering stage } & \multicolumn{3}{|c|}{ Full flowering stage } & \multicolumn{5}{|c|}{ Post flowering stage } \\
\hline & & \multicolumn{5}{|c|}{ Harvesting times } & \multicolumn{3}{|c|}{ Harvesting times } & \multicolumn{5}{|c|}{ Harvesting times } \\
\hline & & RI Adams & $9 \mathrm{am}$ & $1 \mathrm{pm}$ & $5 \mathrm{pm}$ & Mean & $9 \mathrm{am}$ & $1 \mathrm{pm}$ & $5 \mathrm{pm}$ & Mean & $9 \mathrm{am}$ & $1 \mathrm{pm}$ & $5 \mathrm{pm}$ & Mean \\
\hline & Thujene $<\alpha^{-}>$ & 930 & 0.65 & 0.66 & 0.65 & 0.65 & 0.80 & 0.82 & 0.83 & 0.82 & 0.50 & 0.41 & 0.40 & 0.44 \\
\hline 3 & Camphene & 954 & 0.72 & 0.72 & 0.73 & 0.72 & 0.98 & 1.01 & 0.96 & 0.98 & tr & $\operatorname{tr}$ & $\operatorname{tr}$ & tr \\
\hline 4 & Sabinene & 975 & 0.41 & 0.38 & 0.39 & 0.39 & 0.40 & 0.37 & 0.39 & 0.39 & 0.37 & 0.45 & 0.45 & 0.42 \\
\hline 5 & Pinene $<\beta$-> & 979 & 0.30 & 0.32 & 0.31 & 0.31 & 0.18 & 0.18 & $\operatorname{tr}$ & 0.12 & 0.25 & 0.32 & 0.34 & 0.30 \\
\hline 6 & Myrcene & 990 & 0.32 & 0.35 & 0.30 & 0.32 & 0.32 & 0.41 & 0.40 & 0.38 & 0.54 & 0.82 & 0.69 & 0.68 \\
\hline 8 & Terpinene $<\alpha^{-}>$ & 1017 & $\operatorname{tr}$ & $\operatorname{tr}$ & $\operatorname{tr}$ & $\operatorname{tr}$ & $\operatorname{tr}$ & $\operatorname{tr}$ & $\operatorname{tr}$ & $\operatorname{tr}$ & $\operatorname{tr}$ & $\operatorname{tr}$ & $\operatorname{tr}$ & tr \\
\hline 9 & Cymene $<\rho^{-}>$ & 1024 & 0.10 & 0.12 & 0.15 & 0.12 & $\operatorname{tr}$ & 0.12 & $\operatorname{tr}$ & $\operatorname{tr}$ & $\operatorname{tr}$ & $\operatorname{tr}$ & $\operatorname{tr}$ & $\operatorname{tr}$ \\
\hline 10 & Limonene & 1029 & $6.77 \mathrm{~b}$ & $6.80 \mathrm{~b}$ & $6.84 \mathrm{~b}$ & 6.80 & $6.94 \mathrm{~b}$ & $7.22 \mathrm{~b}$ & $7.21 \mathrm{~b}$ & 7.12 & $8.85 \mathrm{a}$ & $9.01 \mathrm{a}$ & $8.88 \mathrm{a}$ & 8.91 \\
\hline 11 & 1,8-Cineole & 1031 & $\operatorname{tr}$ & 0.17 & 0.33 & 0.17 & 0.30 & 0.50 & 0.41 & 0.40 & 0.15 & 0.22 & 0.21 & 0.19 \\
\hline 12 & Ocimene $<(\mathrm{Z})-\mathrm{B}->$ & 1037 & 0.50 & 0.50 & 0.54 & 0.51 & 0.82 & 0.75 & 0.69 & 0.75 & 0.32 & 0.44 & 0.44 & 0.40 \\
\hline 13 & Ocimene $<(E)-\beta->$ & 1050 & 0.40 & 0.42 & 0.42 & 0.41 & 0.60 & 0.82 & 0.78 & 0.73 & 1.04 & 1.10 & 1.12 & 1.09 \\
\hline 14 & Terpinene $<\mathrm{Y}^{->}$ & 1059 & 2.14 & 2.19 & 2.16 & 2.16 & 0.30 & 0.28 & 0.19 & 0.26 & 3.67 & 4.12 & 4.40 & 4.06 \\
\hline 15 & Fenchone & 1086 & $12.46 \mathrm{~b}$ & $14.55 \mathrm{a}$ & $14.67 \mathrm{a}$ & 13.89 & $12.04 \mathrm{~b}$ & $13.1 \mathrm{~b}$ & $13.0 \mathrm{~b}$ & 12.71 & $8.81 \mathrm{c}$ & $8.92 \mathrm{c}$ & $8.89 \mathrm{c}$ & 8.87 \\
\hline 16 & Terpinolene & 1088 & $\operatorname{tr}$ & 0.16 & 0.15 & 0.10 & $\operatorname{tr}$ & 0.16 & 0.15 & 0.10 & $\operatorname{tr}$ & 0.15 & 0.13 & tr \\
\hline 19 & Borneol & 1169 & tr & 0.13 & 0.15 & $\operatorname{tr}$ & $\operatorname{tr}$ & 0.15 & 0.15 & 0.10 & $\operatorname{tr}$ & $\operatorname{tr}$ & $\operatorname{tr}$ & tr \\
\hline 20 & Terpinen-4-ol & 1177 & 0.35 & 0.50 & 0.44 & 0.43 & 0.73 & 0.70 & 0.70 & 0.71 & $\operatorname{tr}$ & $\operatorname{tr}$ & $\operatorname{tr}$ & $\operatorname{tr}$ \\
\hline 21 & Terpineol $<\alpha^{-}>$ & 1188 & 0.18 & 0.20 & 0.20 & 0.19 & 0.45 & 0.31 & 0.28 & 0.35 & $\operatorname{tr}$ & $\operatorname{tr}$ & $\operatorname{tr}$ & tr \\
\hline 22 & Estragole & 1196 & 2.07 & 2.20 & 2.41 & 2.23 & 1.07 & 1.20 & 1.41 & 1.23 & 1.24 & 1.10 & 1.32 & 1.22 \\
\hline 23 & Fenchyl acetate (exo) & 1232 & $\operatorname{tr}$ & $\operatorname{tr}$ & $\operatorname{tr}$ & $\operatorname{tr}$ & $\operatorname{tr}$ & 0.12 & 0.12 & $\operatorname{tr}$ & $\operatorname{tr}$ & $\operatorname{tr}$ & $\operatorname{tr}$ & $\operatorname{tr}$ \\
\hline 24 & Anethole (Z) & 1252 & 1.43 & 1.58 & 1.63 & 1.55 & 1.50 & 1.58 & 1.54 & 1.54 & 3.29 & 3.60 & 4.12 & 3.67 \\
\hline 25 & Anethole (E) & 1284 & $42.02 \mathrm{~d}$ & $42.15 \mathrm{~d}$ & $42.00 \mathrm{~d}$ & 42.06 & $49.92 \mathrm{c}$ & $50.30 \mathrm{c}$ & $50.90 \mathrm{bc}$ & 50.37 & $52.00 \mathrm{ab}$ & $53.18 \mathrm{a}$ & 52.14ab & 52.44 \\
\hline 26 & Anisaldehyde (meta) & 1196 & tr & nd & nd & $\operatorname{tr}$ & $\operatorname{tr}$ & $\operatorname{tr}$ & $\operatorname{tr}$ & $\operatorname{tr}$ & nd & nd & nd & nd \\
\hline 27 & Germacrene D & 1481 & 3.47 & 3.50 & 3.49 & 3.49 & 2.12 & 2.15 & 2.15 & 2.14 & 0.72 & 0.75 & 0.70 & 0.72 \\
\hline \multirow[t]{7}{*}{28} & Caryophyllene oxide & 1583 & $\operatorname{tr}$ & 0.13 & 0.12 & $\operatorname{tr}$ & $\operatorname{tr}$ & 0.12 & 0.11 & $\operatorname{tr}$ & nd & nd & nd & nd \\
\hline & Monoterpen hydrocarbons & & 26.25 & 26.61 & 26.67 & 26.51 & 26.57 & 27.84 & 26.00 & 26.80 & 28.41 & 29.96 & 29.76 & 29.38 \\
\hline & Monoterpen oxygeneted & & 58.74 & 61.98 & 62.35 & 61.02 & 66.40 & 68.18 & 68.76 & 67.78 & 65.63 & 67.38 & 66.88 & 66.63 \\
\hline & Sesquiterpen hydrocarbons & & 3.47 & 3.50 & 3.49 & 3.49 & 2.12 & 2.15 & 2.15 & 2.14 & 0.72 & 0.75 & 0.70 & 0.72 \\
\hline & Sesquiterpen oxygeneted & & $\operatorname{tr}$ & 0.13 & 0.12 & $\operatorname{tr}$ & $\operatorname{tr}$ & 0.12 & 0.11 & $\operatorname{tr}$ & $\operatorname{tr}$ & $\operatorname{tr}$ & $\operatorname{tr}$ & tr \\
\hline & Others & & $\operatorname{tr}$ & $\operatorname{tr}$ & $\operatorname{tr}$ & $\operatorname{tr}$ & $\operatorname{tr}$ & 0.12 & 0.12 & $\operatorname{tr}$ & $\operatorname{tr}$ & $\operatorname{tr}$ & $\operatorname{tr}$ & $\operatorname{tr}$ \\
\hline & Volatile oil yield (\%) & & $\begin{array}{l}1.62 \mathrm{c} \\
8846\end{array}$ & $\begin{array}{l}1.71 \mathrm{c} \\
-92\end{array}$ & $1.72 \mathrm{c}$ & 1.68 & $2.10 \mathrm{~b}$ & $2.25 \mathrm{a}$ & $\begin{array}{r}2.20 \mathrm{ab} \\
07.14\end{array}$ & 2.18 & $0.78 \mathrm{~d}$ & $0.84 \mathrm{~d}$ & $0.81 \mathrm{~d}$ & 0.81 \\
\hline
\end{tabular}

RI Adams: Identification based on comparison of retention index those of published data (Adams, 2017), Retention indices relative to n-alkans (C5-C22) on HP 5MS column, tr: Trace ( $<0.1)$. 
a-pinene, a-phellandrene and limonene) were the dominant compounds of the essential oils, with the ranges of $39.10^{-77.04 \%}$ and $13.45-59.16 \%$, respectively (Table 1). Germacrene-D and caryophyllene oxide were the only sesquiterpenes identified, representing 0.70 $3.63 \%$ of the whole plant volatile oil, with a decreasing trend from pre-flowering stage to post-flowering. Oxygenated monoterpenes increased from $45.74 \%$ of leaf to $56.64 \%$ of root-bulb-stalk, to $67.16 \%$ of flower, and to $73.56 \%$ of seed, as a mean of plant organs. The average of monoterpene hydrocarbons, on the contrary, decreased substantially from $51.89 \%$ of leaf to $32.81 \%$ of root-bulb-stalk, to $29.72 \%$ of flower, and to $18.06 \%$ of seed. The amount of monoterpenes oxygenated of immature seed essential oil was nearly 2 times greater than that of leaf at full-flowering, whereas monoterpene hydrocarbons of immature seed essential oil was $77.04 \%$ lower as compared to that of the leaf samples of full-flowering stage. Inter- and intravariability of oxygenated monoterpenes and monoterpene hydrocarbons in essential oils of whole the plants harvested at three different hours in a day were relatively small, within the ranges of 58.74$68.76 \%$ and $26.00-29.96 \%$, respectively. Bitter fennel essential oils were characterized by the dominant presence of trans-anethole, a-pinene, a-phellandrene, limonene, and fenchone as the major constituents, varying significantly with the stages of plant growth and plant organs. Trans-anethole was found to be the most prominent compound in all esssential oils, with increasing order in root-bulb-stalk < leaf < flower < immature seed essential oils, ranging in concentration from $29.64 \%$ to $56.20 \%$. The contents of trans-anethole $(56.20 \%)$ and fenchone (15.70) were the highest in immature and mature seed essential oils, respectively. The highest contents of a-pinene $(23.12 \%)$ and aphellandrene $(22.58 \%)$ were obtained from bitter fennel essential oil of the leaf at full-flowering stage, while the lowest amounts $(5.08 \%$ and $1.12 \%$, respectively) were in immature seed. The contribution of limonene to essential oil was the highest in flower of full-flowering. The amount of trans-anethole and limonene increased regularly with the progres in plant growth, whereas the contribution of fenchone to the the essential oil decreased. The findings of previous studies carried out in Brazil (Stefanini et al., 2006), Pakistan (Anwar et al., 2009), China (Diao et al., 2014), Iran (Bahmani et al., 2016), and Egypt (Wahba et al., 2018) are consonant with our results, indicating that trans-anethole was the major essential oil constituent. In our study, essential oil of immature seed contained higher amount of trans anethole than that of mature seed. This result differs from that of Anwar et al. (2009), who found that the content of transanethole regularly increased from immature to mature fruit. Essential oil profile obtained in the present study was similar to the previous results in Turkish bitter fennel reported by Akgul and Bayrak (1988) who found that trans-anethole, increasing regularyl from leaf to fruit, was the major constituent of all volatile oil samples. The present results, showing trans anethole as the major constituent of all essential oils, are in good agreement with those of Dadalioglu and Evrendilek (2004), Cosge et al. (2008) and Coban et al. (2018) reporting trans-anetholewas the main constituent in essential oil of fennel from Turkey. The previous studies from Sudan (Hassan and Elhassan, 2017) and Tunisia (Khammasshi et al., 2017), however, reported that estragole was the major component of fennel essential oil. Ozcan and Chalchat (2006)reported that estragole, limonene, and fenchone were the main components in bitter fennel native to Turkey. Estragole (61.08\%), fenchone (23.46\%), and limonene $(8.68 \%)$ were reported as the main constituents in the essential oils of fully matured fruit of bitter fennel (Ozcan et al., 2006). As reported by Ozcan and Akgul (2001), the essential oils of bitter fennel fruits from Turkey contained estragole (47.09\%), limonene (29.07\%), and fenchone (13.43\%) as the main constituents. The results of the present study revealed a complementary trend of oxygenated monoterpenes and monoterpene hydrocarbons during plant growth; the relative content of oxygeneted monoterpenes increased from leaves to immature seeds, while that of monoterpene hydrocarbones decreased. A study by Ferioli et al. (2017) confirmed these results, indicating that during plant growth from leaves to fruits the content of non-oxygenated monoterpenes decreased, but oxygenated monoterpenes increased.

\section{CONCLUSIONS}

The results of the present study revealed that the contents and constituents of bitter fennel essential oil varied significantly in accordance with the growth stage and plant organ, with a non-significant diurnal variability. The mean essential oil content increased in the order of leaf $<$ flower <seed, with a nearly sevenfold increase occurring in seed essential oil as compared to that of leaf. These findings suggest that, essential oil content of bitter fennel increase regularly with the progress in plant growth; the later the plant growth stage, the higher the essential oil content is. However, when considering each plant organ separately, this turned vice versa and the essential oil content decreased with maturity; higher essential oil in younger leaf and immature seed than in older and mature ones. Oxygenated monoterpenes (transanethole and fenchone) and monoterpene hydrocarbons (a-pinene, a-phellandrene and limonene) were the dominant compounds of the essential oils. The content of oxygeneted monoterpenes progressively increased from leaves to immature seeds, while relative amount of monoterpene hydrocarbones follewed the opposite patterns. In all essential oils from 
all plant organs harvested at all growth stages, transanethole appeared as the most prominent component with a two-fold increase in immature seed compared to leaf. In conclusion, these results outline the fact that content and constituents of bitter fennel essential oil are predominantly dependent on ontogenetical phase and plant organ and immature seed produced the highest amount of essential oil with transanethole as the main component.

\section{ACKNOWLEDGEMENTS}

Authors are highly thankful to Scientific Research Projects Unit (BAP) of Ordu University for providing support to this research, as a part of AR-1317 BAP project. This study was presented at The International Conference on Agriculture, Forest, Food Sciences and Technologies (ICAFOF), held in Urgup/Turkey during 15-17 May, 2017.

\section{Statement of Conflict of Interest}

Authors have declared no conflict of interest.

\section{Author's Contributions}

The contribution of the authors is equal.

\section{REFERENCES}

Açıkgöz MA, Kara SM, Aruc C, Ay E 2017. Morphogenetic, Ontogenetic and Diurnal Variability in Antimicrobial Activity of Bitter Fennel (Foeniculumvulgare Miller var. vulgare) Essential Oil. Indian Journal of Pharmaceutical Education and Research,51(3): 190-194.

Adams RP 2017. Identification of Essential Oil Components by Gas Chromatography/Mass Spectrometry. Texensis Publishing, $5^{\text {th }}$ Ed. (Online), Gruver, TX USA.

Akgul A, Bayrak A 1988. Comparative Volatile Oil Composition of Various Parts from Turkish Bitter Fennel (Foeniculum vulgare var. vulgare). Food Chemistry,30(4): 319-323.

Anwar F, Hussain AI, Sherazi STH, Bhanger MI 2009. Changes in Composition and Antioxidant and Antimicrobial Activities of Essential Oil of Fennel (Foeniculum vulgare Mill.) Fruit at Different Stages of Maturity. Journal of Herbs, Spices and Medicinal Plants,15(2): 187-202.

Badgujar SB, Pate IVV, Bandivdekar AH 2014. Foeniculum vulgare Mill: A Review of Its Botany, Phytochemistry, Pharmacology, Contemporary Application, and Toxicology. BioMed Research International,2014: 01-32.

Bahmani K, Izadi DA, Alfekaiki DF, Sticklen M 2016. Phytochemical Diversity of Fennel Landraces from Various Growth Types and Origins. Agronomy Research,14(5): 1530-1547.

Choi EM, Hwang JK 2004. Anti-Inflammatory, Analgesic and Antioxidant Activities of The Fruit of
Foeniculum vulgare. Fitoterapia, 75: 557-565.

Coban C, Ozer H, Ors S, Sahin U, Yildiz G, Cakmakci T 2018. Effects of Deficit Irrigation on Essential Oil Composition and Yield of Fennel (Foeniculum vulgare Mill) in A High-Altitude Environment. Journal of Essential Oil Research,30(6): 457-463.

Cosge B, Kiralan M, Gurbuz B 2008. Characteristics of Fatty Acids and Essential Oil from Sweet Fennel (Foeniculum vulgare Mill. var.dulce) and Bitter Fennel Fruits ( $F$. vulgare Mill. var. vulgare) Growing in Turkey. Natural Product Research,22(12): 1011-1016.

Dadalioglu I, Evrendilek GA 2004. Chemical Compositions And Antibacterial Effects of Essential Oils of Turkish Oregano (Origanumminutiflorum), Bay Laurel (Laurusnobilis), SpanishLavender (Lavandulastoechas L.), and Fennel (Foeniculum vulgare) on Common Foodborne Pathogens. Journal of Agricultural and Food Chemistry, 52:8255-8260.

Diao WR, Hu QP, Zhand H, Xu JG 2014. Chemical Composition, Antibacterial Activity and Mechanism of Action of Essential Oil From Seeds of Fennel (Foeniculum vulgare Mill.). Food Control,35(1):109-116.

Ferioli F, Giambanelli E, D’Antuono LF 2017. Fennel (Foeniculum vulgare Mill. subsp. piperitum) Florets, A Traditional Culinary Spice in Italy: Evaluation of Phenolics and Volatiles in Local Populations, and Comparison with the Composition of other Plant Parts. Journal of the Science and Food and Agriculture,97: 536-5380.

Figueredo G, Ozcan MM, Chalchat JC 2011. Effect of Harvest Years on Chemical Composition of Essential Oils of Bitter Fennel (Foeniculum vulgare Mill. subsp. piperitum) Fruits. Journal of Food Biochemistry,35: 1223-1230.

García-Jiménez N, Péerez-Alonso MJ, VelascoNegueruela A 2000. Chemical Composition of Fennel Oil, Foeniculum vulgare Miller, from Spain. Journal of Essential Oil Research,12(2): 159-162.

Hassan OM, Elhassan IA 2017. Characterization of Essential Oils from Fruits ofUmbelliferous Crop Cultivated in Sudan II. Coriandrumsativum L. (Coriander) and Foeniculum vulgare Mill (Fennel).Journal of Pharmacognosy and Phytochemistry,6(1): 113-116.

He W, Huang B 2011. A Review of Chemistry and Bioactivities of A Medicinal Spice: Foeniculum vulgare. Journal of Medicinal Plants Research, 5(16): 3595-3600.

Kara SM, Acikgoz MA 2018.Morphogenetic, Ontogenetic and Diurnal Variability in Antioxidant Activity, Total Phenol and Flavonoids of Foeniculum vulgare Miller var. vulgare Extracts. YuzuncuYil University Journal of Agricultural Sciences,28 (Special issue): 96-101.

Khammassi M, Loupassaki S, Tazarki H, Mezni F, Slama A, Tlili N, Zaouali Y, Mighri H, Jamoussi B, 
Khaldi A 2018. Variation in Essential Oil Composition and Biological Activities of Foeniculum vulgare Mill. Populations Growing Widely in Tunisia. Journal of Food Biochemistry,42(3), e12532.

Khan M, Musharaf S 2014. Foeniculum vulgare Mill. A Medicinal Herb. Medicinal Plant Research,4(6): 46-54.

Lee YL, Ding P 2016. Production of Essential Oil in Plants: Ontogeny, Secretory Structures and Seasonal Variations.Pertanika Journal of Scholarly Research Reviews,2(1): 1-10.

Marotti M, Piccaglia R, Giovanelli E, Deans SG, EagleshamE1994. Effects of Variety and Ontogenic Stage on the Essential Oil Composition and Biological Activity of Fennel (Foeniculum vulgare Mill.). Journal of Essential Oil Research,6(1): 57-62.

Ozcan M, Akgul A 2001. Chemical Composition of the Essential Oil of Bitter Fennel (Foeniculum vulgare subsp. piperitum). Journal of Spices and Aromatic Crops, 10(1): 49-50.

Ozcan MM, Chalchat JC 2006. Effect of Collection Time on Chemical Composition of the Essential Oil of Foeniculum vulgare subsp. piperitumGrowing Wild in Turkey. European Food Research and Technology,224: 279-281.

Ozcan MM, Chalchat JC, Arslan D, Ates A, Unver A
2006. Comparative Essential Oil Composition and Antifungal Effect of Bitter Fennel (Foeniculum vulgare ssp. piperitum) Fruit Oils Obtained During Different Vegetation. Journal of Medicinal Food,9(4): 552-561.

Rather MA, Dar BA, Sofi SN, Bhat BA, Qurishi MA 2016. Foeniculum vulgare: A Comprehensive Review of Its Traditional Use,Phytochemistry, Pharmacology, and Safety.Arabian Journal of Chemistry,9: 1574-1583.

Stefanini MB, Ming LC, Margues OCM, Facanali R, Meireles MAA, Moura LS, Marchese JA, Sousa LA 2006. Essential Oil Constituents of Different Organs of Fennel (Foeniculum vulgare var. vulgare). The medicinal Journal of Medicinal Plants,8: 193-198.

Telci I, Demirtas I, Sahin A 2009. Variation in Plant Properties and Essential Oil Composition of Sweet Fennel (Foeniculum vulgare Mill.) Fruits During Stages of Maturity. Industrial Crops and Products, 30(1): 126-30.

Wahba HE, Ibrahim ME, Mohamed MA 2018. Comparative Studies of The Constituents of Fennel Essential Oils Extracted from Leaves and Seeds with Those Extracted from Waste Plants after Harvest. Journal of Materials and Environmental Sciences,9(7): 2174-2179. 